\title{
Sustainable Forest Management in Mexico
}

\author{
Juan Manuel Torres-Rojo ${ }^{1} \cdot$ Rafael Moreno-Sánchez $^{2}$ • \\ Martín Alfonso Mendoza-Briseño ${ }^{3}$
}

Published online: 11 April 2016

(C) Springer International Publishing AG 2016

\begin{abstract}
Forest management in Mexico is immersed in diverse and complex ecological, socio-cultural, political, economic, and technological contexts. These contexts have led to the use of the forests for many purposes under diverse administration and management schemes. These schemes continue to evolve, both in the forest areas and in universities and forest research institutions throughout the country. Timber management has been part of this evolution and has given rise to several forest management approaches. Most of these approaches are adaptations of methods developed in other parts of the world for very different ecological, socio-cultural, and economic contexts. The majority of the timber management methods are based on sustainability principles and incorporate classical yield regulation and forest management concepts. However, the
\end{abstract}

This article is part of the Topical Collection on Integrating Forestry in Land Use Planning

Juan Manuel Torres-Rojo

juanmanuel.torres@cide.edu

Rafael Moreno-Sánchez

Rafael.Moreno@ucdenver.edu

Martín Alfonso Mendoza-Briseño

mmendoza@colpos.mx

1 Centro de Investigación y Docencia Económicas, A.C. (CIDE), Carr. México-Toluca 3655, Col. Lomas de Santa Fe, México, D.F. 01210, México

2 Department of Geography and Environmental Sciences, University of Colorado Denver, Campus Box 172 P.O. Box 173364, Denver, CO 80217-3364, USA

3 Colegio de Posgraduados, Campus Veracruz, Carr. Jalapa-Veracruz Km. 88.5, Manlio Fabio Altamirano, Veracruz, México application of these methods in the complex and rapidly changing contexts in which the Mexican forests and forestry sector are immersed has resulted in unexpected and fortuitous results. There is a need for a new significant evolution of the forest and timber management methods in the country. New approaches must include greater emphasis on communitybased forestry, consideration of markets for forest products and services, as well as the overall increase of resilience, learning capacity, and adaptation while reducing hazards, risks, and vulnerability of the forests and the communities that depend on them. These characteristics will allow better adaptation to the rapid changes, complexities, and ambiguities of the global environment and the Mexican ecological, social, political, and economic conditions.

Keywords Forest conservation management · Timber management $\cdot$ Social forestry $\cdot$ Tropical timber management

\section{Introduction}

The forests in Mexico cover roughly a third of the national territory (65 million hectares). Temperate forests cover $51 \%$ of this area, and the remaining $49 \%$ is covered by tropical forests [1]. The geographical location of the country at the confluence of the neartic and neotropical biogeographic zones, its long north-south shape and its complicated topography create a large diversity of climates and microenvironmental conditions that give rise to highly diverse forest ecosystems and site conditions [2].

This ecological diversity is found in locations with very diverse population densities and socio-cultural and economic conditions [2]. Most of the forests in the central and southern part of the country are fragmented and under high land-use pressures from high population densities within the forests, as 
well as from urban, agricultural, and livestock activities at their edges. In contrast, the forests in the mountain ranges of the north-west cover extensive areas and have lower population densities $[3,4 \bullet \bullet, 5]$.

The forest areas in Mexico have well-defined property rights and many people live within or at the edge of the forests and depend on them to make a living. Roughly $7-12 \%$ of the forest lands in the country are owned by the state in the form of national forests and forest reserves, while private owners hold a little more than $30 \%$ (usually in the best site conditions). The remaining $61 \%$ are owned by communities in the form of collective land ownerships such as "Ejidos" or indigenous land holdings known as "Comunidades" [6-8].

The diversity in the ecological, socio-cultural, and economic contexts in which the forest areas are immersed has given rise to different strategies and methods for the management of the forest resources in Mexico. The traditional forest management objective of timber production is not common in many forest areas. Often, forest owners have no timber production objective at all, and objectives such as conservation, harvesting of nontimber products, protection of religious and ceremonial sites, and provision of forest services (e.g., water production, recreation, carbon sequestration) have a higher priority $[4 \cdot \bullet, 6]$.

Even, when timber production is declared as the main management objective, it is usually accompanied by ancillary objectives to produce diverse nontimber products and services. Socio-economic conditions over the forest areas are varied and rapidly changing in space and time. Policies, laws, regulations, and administration arrangements for the management of the forests change frequently and are rather varied across the country. There are multiple deforestation and degradation pressures emerging from populations living below the poverty level that need to satisfy basic necessities. In this context, traditional timber management principles such as regulation of harvest flows, sustained yield, and long-term timber productivity do not apply and have been modified in Mexican forest management methods to accommodate these realities. These management methods have appeared in response to and coevolve with these forests and forestry sector conditions.

The review presented here discusses forest management approaches and methods used in Mexico during different time periods. It concentrates on timber management methods, but includes a brief overview of forest management approaches with other set of objectives. We highlight the diversity of timber management approaches that have appeared over time in response to changes in the contexts of the forests and forestry sector. These methods have evolved in response to changes in needs, management paradigms, and availability of information and analytical tools. We argue that the dominant timber management methods being used today in Mexico are unfit to address the current realities of the forests and forestry sector in the country. We conclude that there is an urgent need to develop timber management approaches that are better capable to deal with the uncertainty, complexity, ambiguity, and rapid change of the global environment and the national and local contexts of the forests in Mexico.

\section{Brief Overview of Nontimber Forest Management in Mexico}

The management objectives for the 65 million hectares of forests in the country are numerous and diverse. Currently, about 6.2 million hectares of temperate and tropical forests are under active management for timber production [9]. However, the forest ownerships that contain these commercial timberlands total close to 15 million hectares because these ownerships on average set between 60 and $65 \%$ of their forest holdings as forest reserves. In these areas, conservation, nontimber products, and the provision of ecosystem services are emphasized allowing only low level of activities such as cattle ranching and tourism. This section briefly describes the management of forests for the purpose of conservation and the production of nontimber goods and services.

\section{Management for Conservation Purposes}

Little more than $8 \%$ of the national forest cover is under "formal" protection in the form of natural protected areas with very low timber management activities and with high emphasis on nontimber products and the provision of forest services. The first national park was created at the end of the nineteenth century [10]. During the 1930s, the area of the national parks increased to reach almost one million hectares [11]. Since the beginning of the 1980s, Mexico started an intense process of creating forest reserves that incorporate both private and communal properties. It is estimated that little more than $72 \%$ of these forest reserves in the country have been established in private properties (individually or socially owned) [12].

At the beginning of this century, all the wildlands set aside for conservation purposes as biosphere reserve, protection areas of flora and fauna, national park, protection areas of natural resources, sanctuary, or monument, were incorporated into the National System of Natural Protected Areas (SINANP) [12]. The SINANP includes terrestrial and marine ecosystems with a total extension of nearly 25.4 million hectares; it only includes 5.7 million hectares of temperate and tropical forests [13].

The areas in the SINANP were established for a variety of reasons such as for their scenic or recreational value. Before the 1990s, their creation was often unrelated to the protection of biodiversity. Hence, their management, even though is related to conservation, does not follow the international standards established for protected areas, which include the definition of a core area for strict conservation that is surrounded by a buffer area where some production activities are allowed 
depending on the biophysical characteristics of the area. Nevertheless, more than $80 \%$ of the SINANP reserves are classified as multiple-use reserves, which allow a wide variety of uses and activities within their borders [12]. Each reserve is required to have a management program that specifies proper uses and conservation activities for the subunits that compose the reserve [14]. However, by 2013, only $44 \%$ of the reserves in the SINANP had a management plan approved [11].

\section{Management for Important Flora and Fauna}

The Units for the Conservation, Management and Sustainable Use of Wildlife (UMA) are composed of wildlands dedicated to the conservation and management of specific flora and fauna species [15]. They are classified as extensive (management of wild populations and habitats) or intensive (management in zoos, botanical gardens, and other small areas) [15]. These units are contained within private or communal land properties and are registered with state or federal environmental authorities to operate in accordance to an approved management plan to harvest individuals of one or more species for which there is a continuous monitoring of habitat and population size. This management model creates economic incentives for biodiversity conservation by allowing landowners and managers to directly benefit from the exploitation of wildlife or flora (e.g., through hunting, harvest, or tourism activities). The basic requirement to register an UMA is to develop a management plan. Such a plan must guarantee the conservation of the ecosystems (especially specific habitats) and viability and survivorship of the wildlife populations within the property, particularly those that are actively harvested [11].

The UMA mechanism has become popular and very successful in the temperate and dry areas of northern Mexico, but it has shown some drawbacks in the tropical southern region of the country $[16,17]$. The problems are related to the ecological and population characteristics of the wildlife in the tropics, the high rate of consumption of wildlife by local forest inhabitants, and the high poverty rates in this region [18]. So far, the system of UMAs has 12,524 units registered covering an area close to 38.2 million hectares. The UMAs located in forest wildlands cover 15 to 18 million hectares [11].

\section{Management for Nontimber Forest Products and Services}

There are extensive areas of forests dedicated to the production of nontimber goods and services. Most of the tropical forests (wet and dry) and very diverse temperate forests have extractive activities of edible (e.g., mushrooms), medicinal, and industrial products (e.g., resin). They also support diverse levels of tourism, cattle ranching, and agro-forestry systems.

The harvesting activities are regulated and they are legally allowed after a management plan that ensures that the sustainability of the resource exploited is approved by the state or federal environmental authorities. However, these authorities do not have the resources to closely monitor and supervise the compliance with the management plans. To date, the harvesting approaches used appear to be sustainable for most of the products despite the deficient supervision; however, some degradation of forest conditions has been reported [19]. Some of the reasons for this degradation are related to bad commercialization channels, the seasonality of most of the extractive activities, and the low harvest rates that are the result of extractive activities being carried out mostly by elder people, women, or children [20,21].

Cattle ranching inside dry and wet tropical forests, oak forests, and mixed pine-oak forests has been widely practiced in the country since colonial times [22]. Sustainable use of the grasslands' carrying capacity is achieved by constant rotations and management of herds; however, soil compaction is a common problem, as well as frequent wildfires resulting from the ranchers' practice of using fire to induce re-budding of grasses [23].

The increasing importance of the role of forests in climate change mitigation has brought new players, considerations, and conservation alternatives into forest management approaches. These alternatives are increasingly becoming attractive for forests with low productivity or high biodiversity where Reduction of Emissions from Deforestation and Degradation (REDD + ) incentives or carbon sequestration markets might yield higher profits than timber extraction. Also, these alternatives are attractive in areas that traditionally have produced timber, but at high production and administration costs as is commonly the case in communally owned forests.

Tourism and recreation in wildlands are activities that are gaining importance and popularity in the country, particularly in areas close to large coastal resorts. In these areas, forest management not only aims to conserve special and interesting habitats but also to protect the tourist areas from threats such as hurricanes, fires, and other environmental hazards as it is the case in the Yucatan peninsula [23].

\section{Management for Timber Production}

This section presents an overview of the emergence, evolution, and characteristics of the most commonly applied timber management methods in the country. First, a brief historical context is provided to support later discussions and to help understand the conditions that led to the appearance of each timber management approach.

\section{Timber Management in Temperate Forests}

Timber extraction during colonial times (1521-1820) was usually done without planning or application of any 
sustainability criteria, and logging was concentrated around centers of high timber demand such as mines and cities [24]. Harvests targeted the most valuable species along easily accessible forest tracks. Despite this chaotic logging practice, concern for the protection of the forests was expressed in the main colonial times legislation the "Laws for the Indias" [25].

The main railroad linking Mexico City with the US border was completed in 1885. It marked the beginning of an increasing demand for more forest products either for operating the railroad system (e.g., sleepers, poles) or to satisfy the demand for other timber products and housing [26]. Forest extraction was conducted by individuals or corporations that were given exclusive concessions of large forest areas along the railroad tracks (or basins of rivers) using clear cuttings; large quantities of timber were wasted because the product finishing was carried out by hand, and small logs were not fully utilized [27]. Many of these harvests produced single-species even-aged forests in some regions of the northern part of the country. Starting in the 1970s, these forests served as test ground for the first applications of even-aged timber management methods in Mexico.

The liquidation of surplus forest resources in some regions of the central and western part of the country characterized the Mexican forestry sector during the first decades of the twentieth century. The public outcry around cases of forest destruction forced authorities to enact the first national forest law in 1926. This law regulated forestry activities on private lands, required plans for harvesting activities, and banned clear cuttings [28]. Most of the forest areas in that period were covered by virgin forests with no infrastructure of any kind (e.g., roads). Hence, there was no previous experience regarding the ecology, logistics of timber procurement, operation costs, and market prices of forest products [27].

Forestry schools in Mexico, as in many countries in the early twentieth century, taught French and German forestry approaches based on the concepts of forest regulation leading to normally stocked forests and aiming to achieve maximum sustained yields [29]. These principles were used to set timber harvest rates under different models trying to ensure some sort of long-term harvest sustainability. However, Mexican foresters soon realized that the forests and socio-economic context for their management were very different from those in Europe, and hence, the strict application of European methods did not completely ensure sustainability or the proper management of the forests [30]. This observation and the social pressure against clear cuttings led to the use of selective cuts as the main silvicultural and harvest treatment regardless of the timber harvest model used. The underlying silvicultural principle was to keep a continuous upper canopy composed of the healthier trees with the best chance to keep growing high value timber products. The selection of trees marked for extraction aimed to come up with a uniform harvest intensity; however, securing the upper residual canopy was a more important goal [31]. Most forests during this period had not received any previous intervention. Hence, the first interventions were improvement cuts to remove old, over mature, or defective trees. Although these harvests were partial selective cuts, they were of sufficient intensity as to change the forest stand structures and ecological conditions to a more dynamic, productive, and healthy condition [32].

These first interventions also liquidated considerable part of the forest standing inventory value converting it to cash to finance badly needed forest infrastructure (e.g., roads), as well as protection and restoration activities (e.g., wildfire suppression). In many areas, forest owners and concessioners seeking to maximize their profits often targeted the largest and best formed trees in the forest to fulfill their allowed harvest volumes. This led to the creation of young forest stands with poor stocking and heterogeneous age structures in which subsequent harvests yielded similar volumes, but considerably less revenues due to the poor quality and size of the timber products extracted [32, 33]. Against this backdrop, the following Mexican forest management methods emerged.

\section{Mexican Method of Forest Regulation (MMFR)}

By the early 1940s, the diversity of forest management and regulation rules and principles existing in the country motivated Mexican foresters to come up with a management method that could be applied around the country to ensure forest sustainability and facilitate the monitoring of harvest activities. The MMFR ("Método Mexicano de Ordenación de Montes") is an uneven-aged forest management method that prescribes harvest of selected trees within a planning horizon defined by the cutting cycle (ranging from 17 to 35 years) using forest management units of 100,000 to 200,000 ha in size [33,34]. The MMFR became the official forest management method for temperate forests in 1944 [31, 35].

The MMFR was developed recognizing four dominant characteristics of the forests and forestry sector in the 1940s [35, 36]: (a) the natural state and ecological diversity of the forests and the need for their regulation; (b) the lack of basic information to manage them such as accurate estimations of growth rates, reliable forest inventories, assessments of forest health conditions, and good maps and area estimates; (c) the lack of institutional and professional experience in forest management planning; and (d) the concern of Mexican society for potential deforestation derived from the application of intensive silvicultural systems like clearcut harvests. Originally, the MMFR was proposed as a temporary method until the forests attained better conditions that would allow the application of traditional area, volume, or area-volume regulation methods [35].

The objective of the MMFR harvest scheduling process is to achieve a steady timber output flow, concentrating harvest operations in a single or few annual cutting areas. The harvest scheduling process requires the consideration of multiple 
alternatives in various combinations. Up to the 1980 s, without the benefit of personal computers, this complex combinatorial problem was tackled through approximations made by hand. The resulting harvest schedules were sufficiently good to allow planning of several large forest units in a way that road construction and timber procurement logistics were carried out efficiently and reliably [37]. Harvest volumes were estimated under the premise that the harvest rate should not be higher than the forest growth rate. Growth rates were estimated by the core growth samples obtained in forest inventories and the simple compound interest rate formula is used to estimate timber volume growth within the cutting cycle. Nowadays, growth models and decision support systems are used for calculations and planning of forest operations in large forest tracks [37].

The MMFR did not specify the use of any particular silvicultural system. However, the selected extraction of trees reaching a minimum diameter was the most common practice, and hence, the MMFR was associated with this form of silviculture. Originally, the MMFR was a single-objective method for timber production. By the early 1980s, several enhancements were made to incorporate the consideration of multiple uses of the forests in determining the optimal number of trees and age structure of the forests remaining after the harvests. Constraints to fulfill social and economic goals such as minimum income flow and employment were also incorporated into the method at that time [38, 39].

Starting in the late 1970 s, some evaluations of the results obtained from the application of the MMFR revealed that the method was leading to the liquidation of old growth, in some cases to the depletion of the growing stocks, and the dominance of fewer tree species [23, 40-42]. These criticisms were widely debated because the sustainability of harvest levels and forest conditions depends on the initial forest condition, the correct application of the MMFR regulation principles, and on the proper estimation of adequate harvest levels [42]. Despite the criticism, the MMFR continued to be the dominant management method in extensive forest areas in the country and it has been applied in one form or another in almost every forest track, scale, and condition in the country.

In the late 1970s, a new national forest law mandated the liquidation of the exclusive concessions of large forest areas to private or state companies and to return the control of the forests to their owners. Private and communal owners started to demand the authorization of more intensive forms of forest management. This new context required a new management approach that would incorporate more intense interventions and harvests. Hence, in the mid-1980s, the "Method for Silvicultural Development" was created [6, 43].

\section{Method for Silvicultural Development (MSD)}

The MSD was conceived as an even-aged forest management method. The seed-trees silvicultural system is commonly prescribed for the final harvest, with rotations between 50 to 80 years, allowing 3 to 4 intermediate thinnings distributed evenly during the rotation period. At the forest level, the MSD adopts an area-volume control to guide the harvests, with cutting priorities aimed to reduce the period for conversion to a regulated forest and to best spatially arrange the harvest areas [44]. The regulation approach ensures the sustainability of the forests as long as the method is applied correctly. However, in some regions with high population densities dominated by small to medium forest ownerships, the large openings in the forests resulting from final harvests facilitate land-use changes to agricultural uses [23]. On the contrary, good applications of the method resulted in higher timber productivity due to the faster growth rate of second-growth forests and the timber yields coming from the intermediate thinnings [45].

The MSD has been modified to adapt it to forests with shade-tolerant species, mixed species, and uneven-aged stands. The aim of these adaptations is to apply silvicultural treatments that proceed at a constant and fast pace to replace the original forest stands with new, optimal-density, even or uneven-aged stands. Treatments usually aim to create forest stands that have the age and density composition of maximum average production (including the yield from all rotation interventions plus mortality). Thinnings are the main tool to adapt the method to uneven-aged stands, since they can be used to reshape a young forest stand getting it closer to full stocking, even spacing, and homogeneous tree sizes of all species present. When the forest species composition allows it, best species are favored through the marking rules applied in the thinnings. In uneven-aged management applications a selective cut is applied functioning as a combination of final harvest and improvement of the residual growing stock.

Other enhancements have been implemented to adapt the MSD to new sustainable forest management paradigms that require incorporation of multiple-use objectives (as mandated in the 1986 National Forest Law), definition of exclusion areas for wildlife habitat and biodiversity conservation, spatial arrangements of specific stands, and establishment of conservation corridors. Some buffer zones within national protected areas are under timber management applying the MSD method enhanced with the use of biodiversity conservation practices such as keeping snags and $\log$ s, conservation of broadleaf species, and mixing the spatial distribution of conservation and timber producing areas [46]. As it was the case with the MMFR, growth models and computational tools have been developed to analyze harvest schedules under the MSD. SICODESI [47••] was the first decision support system designed to assist managers in the estimation and analysis of harvest schedules. More sophisticated systems have been developed since SICODESI. They have among other improvements incorporated geographical analysis and harvest optimization tools $[47 \bullet \bullet]$. 


\section{Combined Methods (CM)}

Sometimes by design and often by fortuitous change in management practices, the management plans for different forest stands within a property end up combining even and uneven aged management systems plus additional practices to better accommodate ecological conditions and optimize timber production. CM started to appear in the 1980s [33, 48].These methods are commonly applied in small to medium size forest properties (2000 to $12,000 \mathrm{ha}$ ) where their use is more efficient not only for the scale factor but also because they facilitate the production of diverse products and services demanded from the forests [49]. The use of CM has also become popular in forests with low timber productivity and high biodiversity, and in ownerships where timber harvesting is a peripheral activity that complements other economic activities carried out by the forest owners.

The use of CM is characterized by three elements: (1) land uses defined by the owner clearly distinguish between production and conservation areas; (2) each stand in the forest area under timber management is assigned a silvicultural system (even-aged or uneven-aged) according to characteristics such as soil type, aspect, slope, biodiversity, forest health, and timber stock; and (3) harvest rates are estimated according to timber yields for each stand from previous cutting cycles, or through estimates from forest growth models. Forests managed under CM have no harvest flow or regulation constraints and have no ultimate desired forest condition besides keeping or increasing the forest productivity and biodiversity, or reaching a condition desired by the forest owner. In recent years, these methods have included participatory planning processes (in community forests), attempts to optimize forest harvest levels, and the conversion of stands with diverse treespecies mixes to stands composed of only one of two species $[33,47 \bullet \bullet]$.

\section{Landscape-Level Forest Management (LLFM)}

In the early 2000s, LLFM was considered the best alternative for forest areas with low intensity utilization or designated as conservation areas. Forest landscape-level simulation models are used in LLFM to estimate forest change through time using spatially referenced data across a broad spatial scale (i.e., landscape scale) which is generally larger than a single forest stand. These models incorporate spatio-temporal processes such as natural disturbances (e.g., wildfires, pests, and diseases) and human interventions (e.g., harvests, thinnings, planting, fire suppression) [50].

Starting in 2002, several forest properties (averaging $3000-5000$ ha in size) with mixed pine-oak forests in the state of Jalisco in west-central Mexico changed their forest management to the LLFM method known as MAPA [51・•]. Besides the emphasis on the reintroduction of natural forest disturbances, MAPA uses accelerated silvicultural regimes known as biopaths to speed up the reconstruction of the natural forest structure and variability as existed in the early twentieth century. This target date was identified as the most recent almost natural condition of the forests. This condition is characterized by overmature crowded forests with excess of oversized, decrepit, damaged, highrisk trees that have growth and reproductive limitations. The aim is to have as much of these fully functional oldgrowth stands well distributed throughout the management area and covering around $60 \%$ of its total area. The rest of the forest should have sufficient young and mature stands to replace the oldgrowth when large catastrophes liquidate them, or when the forest is intentionally sent back to an early successional stage structure. At least $15 \%$, but no more than $40 \%$, of the area dedicated to timber production should be permanently without tree cover, in forest openings of size between 0.5 and 100 ha each. Open to wooded gradients should become interphases carefully managed to meet multiobjective purposes (biodiversity, interior tree health, low visibility into interior forest environment) $[51 \bullet \cdot]$.

Roads and the associated areas of influence are also managed under a specific silvicultural system to stabilize cuts and fills, and for managing sunlight penetration. Special ecological conditions (e.g., riparian areas, ridge tops) are also managed under special intensive silviculture practices with multiple objectives beyond timber production. Natural or accidental disturbance events are viewed as cost saving windfalls. Silvicultural intervention then is an undesired labor executed when random events (fire, pests, weather, or animal damage) take too much time to move current structures to the desired next condition [51・•].

Harvest schedules are estimated from a complex combinatorial problem. Tabu Search is used to approximate good solutions to the problem. The forest owner, under advice of a professional forester, selects from those solutions the plan that better meets his income expectations, risk tolerance, and strategy regarding the management of his forests. So far, new forest plans have been drafted for several forest ownerships in Jalisco, raising the total area managed by this landscape method to nearly 15,000 ha $[51 \bullet \bullet]$.

\section{Management of Uneven-Aged Multi-Species Forests}

Most of the temperate forests in Mexico are composed of uneven-aged multispecies stands. Current concerns for biodiversity conservation, increasing reliance on the forests, and securing their long-term productivity, join with rising demands for nontimber goods and forest services have provided incentives for research to test alternative ways of managing these complex forests. In the 1990s, some forests in northern Mexico started to be managed using the principles of balanced 
size distributions [52]. Under this management system, harvests are estimated for each diameter class using the difference between the ideal number of trees in a particular diameter class and the number of trees that currently exist in that class. The goal is to create an optimal residual forest growing stock and forest structure that promotes a healthy and resilient forest with adequate diversity [53]. The method has not been used extensively because of the complexity in defining the optimal residual growing stock, diameter-class distribution, and species composition, as well as the difficulty in maintaining them in the long run.

Recent research on this type of forest shows that the relationship between timber yield and forest density could be used as the main guide to manage them [54]. This relationship can be enhanced to include species diversity and site conditions to derive simple rules to guide timber harvest decisions at the stand level that guarantee maximum yields from the residual stock. Forest composition is a key in the management strategy and is monitored at the forest level [45].

\section{Timber Management in Tropical Forests}

From the outset, it is important to note that the knowledge and tools for the management of tropical forests lag behind those available for the temperate forests. This is due to the ecological complexity and socio-cultural-economic conditions particular to this type of forest.

Since pre-Columbian times, the tropical forests in all parts of Mexico, but especially in the Yucatan peninsula have been managed through variations of the slash-and-burn system with multiple production purposes [55]. The system clears out plots from 1 to 5 ha for multicropping, shifting locations every 2 to 5 years according to a comprehensive plan that includes managing the forest regrowth successional stages according to needs and traditions [56]. The system usually incorporated landscape management units [57], and at this level, it had rotations between 30 and 40 years for different forest successional stages $[58,59]$.

Far from being an inefficient and destructive form of land management, this long-term agroforestry system produced a multitude of useful plant resources, protected and enriched the soil, provided wildlife habitat, and maintained a forest cover in original forest lands [60-62]. The increase in the population within the tropical areas, colonization by people not familiar with tropical ecosystems, and the loss of traditional knowledge and uses of biodiversity have created the inefficiencies found in this system today, as well as the loss of extensive tropical forests due to forest degradation and savannization $[63,64 \cdot]$. In other regions, abandonment of agricultural lands has allowed the growth of secondary forests with biomass, productivity, physiognomy, species composition, and community dynamics that greatly differ from the original natural forests [65].
Beginning in the sixteenth century and up to the nineteenth century dyewood (Hematoxylon campechianum) and mahogany (Swietenia spp.) were extracted by American and British loggers along the tropical coast of the Yucatan Peninsula, resulting in the depletion of dyewood and severe liquidation of mahogany [66]. During colonial times and up to the midtwentieth century, no planned management of the tropical forests was carried out [67].

\section{Management of Semideciduous Tropical Forests}

The first modern attempt at tropical timber management in Mexico can be traced back to 1957 in the Yucatan peninsula with the establishment of the federal-government-owned company Maderas Industrializadas de Quintana Roo (MIQRO). The company was granted a concession for 25 years for the management of 550,000 ha of semideciduous tropical forests $[68,69]$. The company developed a management method based on the MMFR. It consisted on harvests applying selection cuts in cycles of 25 years. Allowable annual harvest volumes were calculated for each of the eight most valuable species (e.g., mahogany Swietenia spp. and red cedar Cedrela spp.) by dividing the total volume of trees of commercial size (i.e., $60 \mathrm{~cm}$ or larger in diameter) by 25 (the years in the concession) [70]. Other less valuable species, almost 200 of them, were ignored and basically remained untouched during the harvesting operations. This was an extremely extensive management approach that utilized only $2 \%$ of the standing forest biomass. In the application of the selection cuts, little effort was made to improve the composition, age structure, and density of the remaining forest; however, every harvestable tree was mapped and logging roads were built specifically to reach those trees, and hence, the impact on soil and residual trees was minimized [69].

In the $1980 \mathrm{~s}$, the management of the forests under the MIQRO's concession was transferred to the forest communities that own them. The forest management method called Plan Piloto Forestal de Quintana Roo (PPF) was created as part of this transition. The PPF incorporated the management of more species, restricted the harvest levels to the estimated current growth of the individual tree species, and delimited areas to be permanently dedicated for conservation [71]. This was an important community-based land use planning exercise that raised awareness of the suitability of areas for specific uses and provided the security necessary to implement long-term forest management planning. The harvest levels determined as part of the PPF rely on estimates of growth and size distribution of the most valuable species. Hence, forest sustainability depends on the accuracy of these estimates, on the existence of demand for timber from a wide variety of species, and on high investments required to promote the regeneration of precious and semiprecious species. The PPF has been recognized as probably the largest, most 
important, and successful tropical forest management operation in Latin America [72, 73]. However, recent assessments characterize it as having several shortcomings such as not including forest health practices and specific guidelines for regeneration of cutting areas, forest density control, forest composition management, and forest growth management, all resulting in limited success of the method [74]. The full advantages (mainly operational) and strict application of the method can only be realized in semideciduous tropical forests that are easily accessible as is the case in the Yucatan peninsula. Unfortunately, most of the wet tropical forests in Mexico are located in areas where the terrain conditions do not allow the implementation of the necessary silvicultural practices considered within the PPF method [23].

\section{Management of Tropical Dry Forests (TDF)}

These forests have been severely impacted by land use change since they are easier to convert to agricultural or grassland uses than wet tropical forests, and their soil fertility is higher than in regions with higher annual precipitation [75]. TDF are mainly managed for nontimber products and timber management is limited to few species with special wood characteristics (color, odor, hardness) which make them suitable for carving handcrafts, furniture, or local house building [75]. Procedures to estimate sustainable harvest levels are very basic due to the limited knowledge of the dynamics of the species within these ecosystems [76]. Forest management is carried out in small units. The goal is to maintain specific forest structures and species diversity between successive cutting cycles. Transition matrices of the number of species and tree-diameter distribution are used to determine species abundance and then estimate harvest levels [77]. Harvest rates of the most valuable species are usually estimated in terms of number of trees by diameter class in a 10-year cycle. The decision of how many trees to harvest of each species in each diameter class depends on estimates of the number of trees added to each diameter class, and the ratio between this ingrowth and the next higher diameter class. This ratio is weighted by the species abundance, and the new ratio is used to define the residual condition of the species for all diameter classes [78].

This management method was recently improved to enhance forest sustainability, allowing temporary variation in the number of trees of particular species and considerations for predicted long-term environmental change [79]. This allows increased extraction levels during favorable periods and restricted management practices during unfavorable ones. Some studies have evaluated the sustainability of harvest levels estimated through these procedures and concluded that they maintain both, an adequate tree species diversity and tree-size distribution [78].

One more management method for tropical dry forests is the Costa Plan (CP) method that has been in use since 1983 on the coast of Jalisco in central-western Mexico [74]. The CP replaces the usual specifications of minimum diameter, intensity of harvests, and cutting cycles by a single criterion that integrates attributes of maturity of a tree jointly with its potential timber yield and the likely effects of a tree's removal on the trees remaining in the forest. The application of this method has been successful in maintaining harvest levels of diverse species and preventing deforestation [74].

\section{Current Context for Timber Management}

Timber management in Mexico is practiced in communal and private forest lands. Communal forests currently under active timber management work under the form of "Community Forest Enterprises" (CFEs) to protect, restore, harvest, log, and industrialize forest lands [80••, 81]. Nationally, the active CFEs have an average forest cover of about 100 ha, and they use only about $60 \%$ of their forests for timber production. Nevertheless, they produce almost $85 \%$ of the timber volume logged in the country [82]. The existing CFEs have low vertical industrial integration, and usually, they sell only standing trees or logs $[80 \bullet \bullet, 82]$. More than $55 \%$ of FCEs and more than $60 \%$ of private forest ownerships sell standing trees to logging contractors [9].

Decision-making processes are more complicated in FCEs. Decisions such as use of resources, harvesting rules, definition of conservation criteria and areas, and logging systems to be used for extractions are prepared by a professional forestry consultant and presented to the Community's General Assembly for discussion and approval. Also, forest management objectives in a communally owned forest are broader than maximization of profits, and involve the improvement of the wellbeing of the community, creation of jobs, conservation of special places (e.g., religious or traditional sites), conservation or promotion of specific species (sometimes noncommercial ones), and the combination and promotion of different economic activities (e.g., orchards, livestock, agriculture) jointly with forestry activities [80••]. Hence, community forestry tends to have lower timber harvest levels, and the usual timber management goals such as forest regulation, achieving efficiency, maximizing profits, or even ensuring a sustained yield of timber are not as important as other community's goals. Furthermore, in many cases, timber production is seen as a cyclical temporary activity that uses some of the community's forest resources to supplement their income, or finance the development of other economic, social or cultural activities $[80 \bullet \bullet, 82]$.

Mexican methods for timber management were developed to manage large forest tracks during the times of large forest concessions. Today, those concessions do not exist and timber management is commonly carried out at the property level, usually in small to medium size forest ownerships (e.g., 500 to 
1000 ha). In few instances, several private forest owners join to manage their forests as a single unit [51••]. In most cases, the properties comprise different land uses and their owners, particularly communal ownerships, in which there is a demand for agriculture and grassland areas. Thus, forest management is just one component of a broader use of a wooded landscape and timber production objectives must be seen as just one component within a broader process of rural development.

Today, timber management in the country faces a wide variety of instruments of public policy and incentives related to the production of timber, nontimber products, and environmental services. The emergence of carbon markets and compensations for avoided deforestation such as the REDD+ initiative have introduced new quasi-products to be considered in forest management decisions. Markets for these quasi-products are developing and they are already having some impact on timber management decisions (e.g., delaying or reducing harvest levels). Income from subsidies such as payments for environmental services, and other incentives aimed to reduce land use change and intensive timber extractions in fragile ecosystems add to the set of alternatives to be considered by the forest owners. To be able to access these incentives and emerging markets, forest and environmental authorities require forest owners to reduce harvest areas, harvest volumes, delaying harvests, or even change silvicultural systems.

The rapidly changing site conditions over small areas, and the complex composition of the forests (in age and species), combined with the need to manage the forests at the property level greatly complicate the management problem, the development of planning tools, as well as the implementation of production and operational practices at an efficient economic scale. Hence, timber production in most cases is a temporal or seasonal activity with low returns that is unable to compete with cheaper imported timber products [7, 23, 81]. This lack of competitiveness has led to the shrinking of the market for Mexican timber products in the last 15 years $[9,83]$. The end result has been a reduction in the number of lumber mills, low investments in logging technology, and few incentives to invest in low-impact harvest methods. Currently, the only competitive timber products are rare high-grade logs or sawnwood or logs of precious species [84].

In the socio-cultural dimension, the inhabitants of the forest areas are for the most part poor. More than $50 \%$ of them live in extreme poverty with challenging health, education, and accessibility conditions. People in forest communities for the most part do not have a tradition of making a living from cultivating and investing in their forests [7, 82, 85]. Obtaining a harvest permit is not an easy task. There are many transaction costs as well as a large volume of associated paper work and complicated bureaucratic processes that have resulted in forestry activities that do not always fully comply with laws and regulations [86]. In addition, recurrent patronizing and unsuccessful government projects to develop forest activities and industries, combined with a complicated legislation for the use of the forest resources, have created a skeptical population unwilling to easily trust new initiatives or technologies [87, 88].

\section{Suggested Components of a Sustainable Timber Management Approach for Mexico}

Most of the dominant timber management methods applied in Mexico today are rough transplants of concepts, ultimate goals, principles, and methods used in other parts of the world that have little or no resemblance to the ecological, socio-cultural, economic, legislative, and institutional contexts of the forests and forestry sector in Mexico. Even though they have been adapted and enhanced through time, these methods have not yet been properly modified to address the current realities of the forests and forestry sector in country. Also, they assume long-term stable ecological, economic, socio-cultural, and legislative conditions that do not exist. There is an urgent need to develop timber management principles and methods based on adaptive and risk management approaches that are flexible and better suited to address the existing risks, uncertainties, complexity, ambiguity, and dynamic change that characterize the forestry sector in Mexico today. The new methods should contribute to enhance the forests' and communities' resilience, learning capacity, and adaptability, while helping to reduce hazards, risks, and vulnerabilities (see [89••, 90]).

Currently, the forests in Mexico are more commonly managed at the small or medium size forest property level. This fragmentation of forest management planning has given rise to scale inefficiencies in forestry operations, and at the forest level is jeopardizing the biodiversity and long-term productivity of the forests. This is particularly true in the central part of the country dominated by small forest properties. This situation requires the creation of policy instruments and management practices that can be applied at different scales to promote or enforce some minimum landscape/forest-level conditions that ensure the conservation of biodiversity and the maintenance of the long-term productivity of the Mexican forest ecosystems.

Landscape fragmentation and small-scale factors influence competitiveness and make long-term timber management a risky business in a dynamic market environment with numerous sources of competitive timber products and substitutes. This situation is exacerbated in the case of complex multiaged and multispecies forests, which are dominant in Mexico. Hence, new timber management strategies should aim to set harvest times and volume levels according to market conditions, owner's needs, and forests conditions that allow the conservation of a residual forest growing stock sufficiently resilient to keep its integrity and future yield. This flexibility 
requires the replacement of the traditional forest regulation ideal and management methods by ad hoc pragmatic silvicultural treatments that can be applied over small areas without any forest-level regulation or ideal forest structure goal in mind except for concentrating on the resilience of the residual forest growing stock.

The social dimension, particularly in communally owned forests, affects traditional decision-making processes since it imposes additional complexities that are not well addressed by long-term deterministic management tools. The communal ownership of the majority of the forests in Mexico by indigenous and/or poor communities is a historical and current issue that must be fully recognized and incorporated into the development of future forest policies and management approaches. In this context, timber management decisions should not depend only on economical or ecological considerations. As forest owners become more knowledgeable about their forests, land use options, and become better organized through proper governance structures, they will become better able to define the best way to manage, not only their forest resources, but all their land resources in a broader context of overall sustainable development.

Recognition of risks and vulnerabilities, as well as the incorporation of risk management into the next generation of forest management methods are essential requirements. Today, the forest ecosystems in Mexico face higher risks of degradation or disappearance as a result of the conditions of the forests and forestry sector previously described, as well as conditions created by recent prolonged droughts (possibly as consequence of Climate Change), population growth, and pressures for land use change [91]. Explicit identification and management of risks and vulnerabilities should be essential elements to guide future timber management decisions. The empirical evidence for the effects of these risks and forest production potential is emerging from data generated by networks of long-term observation of forest ecosystems that complement the traditional national forest inventories [92]. These long-term forest observation studies (FOS) are been increasingly established in regions that have similar socioecological conditions (e.g., China and India) as part of their national "Green Infrastructure." FOS have become an essential complement to national resource inventories by providing scientific evidence about forest ecosystem changes in response to environmental change and human use $[93 \bullet \bullet$.

Finally, new management methods should better match management scales (e.g., stand or property) with decisionmaking scales beyond the property level (e.g., watershed or landscape). Ideally, timber management objectives and interventions should be coordinated in a context of overall rural development at the level of landscape management units.

\section{Conclusions}

Currently, most of the semideciduous tropical forests in Mexico are managed under the group selection method enriched with reforestation of commercial species and limited forest level regulation constraints. Temperate forests are mostly managed under uneven-aged systems combining group selection with traditional selective approaches depending on site, diversity, and market conditions. Very few temperate forests are managed under intensive even-aged systems.

In all cases, current forest management systems have evolved from traditional silviculture and forest management principles to adjust to diverse socio-economic contexts and institutional frameworks. Although these methods have been modified and adapted through time, they are not still suited to properly address the current conditions of the forests and forestry sector in the country. There is an urgent need to develop novel forest management approaches, goals, and technologies that are relevant to the new realities of the forest areas in the ecological, socio-cultural, economic, legislative, and institutional dimensions.

The new generation of timber management approaches should combine and adapt traditional forest management concepts such as "multiple-use management," "ecosystem management," and "landscape management" to the specific conditions of each community and forest area using an adaptive and risk management approach. These approaches must emerge from the information provided by FOS and must be flexible enough to be able to address the risks, uncertainties, complexity, and ambiguity created by local and global environmental and socio-economic factors that influence the forests and the communities that depend on them for their survival and development.

\section{Compliance with Ethical Standards}

Conflict of Interest Drs. Torres-Rojo, Moreno-Sánchez, and MendozaBriseño state that they have nothing to disclose.

Human and Animal Rights and Informed Consent This article does not contain any studies with human or animal subjects performed by the author.

\section{References}

Papers of particular interest, published recently, have been highlighted as:

- Of importance

•. Of major importance

1. Food and Agriculture Organization (FAO). Forest Resource Assessment 2010: Mexico. United Nations, FAO, Forestry, FRA 2010/132; 2010. 98 p. 
2. Comisión Nacional para el uso de la Biodiversidad (CONABIO). La diversidad biológica en México: Estudio del País. Ciudad de México, México. Comisión Nacional para el Conocimiento y Uso de la Biodiversidad, 1998. $291 \mathrm{p}$.

3. Moreno-Sánchez R, Torres-Rojo JM, Moreno-Sánchez F, Hawkins $\mathrm{S}$, Little J, MacPartland S. National assessment of the fragmentation, accessibility and anthropogenic pressure on the forests in Mexico. J For Res. 2012;23:529-41.

4.• Sarhukhán J, Carabias J, Koleff P, Hurquiza-Haas T. Capital Natural de México: Acciones estratégicas para su valoración, preservación y recuperación. Ciudad de México: Comisión Nacional para el Conocimiento y Uso de la Biodiversidad; 2012. 95 p. The text shows a complete analysis on the social, economic, physical, biological and cultural situation of natural areas in Mexico.

5. Moreno-Sanchez R, Buxton-Torres T, Silbernagel K. Fragmentation of the forests in Mexico: national level assessments for 1993, 2002 and 2008. Int J Stat Geog. 2014;5:4-17.

6. Bray DB, Merino-Pérez L. The rise of community forestry in Mexico: History, concepts, and lessons learned from twenty-five years of community forestry timber production. Mexico City, Mexico: Secretaria de Medio Ambiente y Recursos Naturales; Instituto Nacional de Ecología. The Ford Foundation; 2002. p. 132.

7. Merino-Pérez L, Segura G. El manejo de los recursos forestales en México (1992-2002) procesos, tendencias y políticas públicas. In: Leef E, Ezcurra E, Pisanty I Romero R, editors. La transición hacia el desarrollo sustentable. Capítulo 10. Ciudad de México: Instituto Nacional de Ecología; 2002. p. 237-256.

8. Madrid L, Núñez JM, Quiroz G, Rodríguez Y. La propiedad forestal social en México. Investigaciones Ambientales. 2009;1:179-96.

9. García-García F. El Desarrollo Forestal Sustentable, eje de la Política de Estado en materia forestal. Taller Regional de Capacitación Guadalajara, Jalisco; 25 de septiembre de 2013. Secretaría de Medio Ambiente y Recursos Naturales, Dirección General de Gestión Forestal y Suelos, México DF, 2013. 12 p.

10. Vargas-Márquez F. Parques Nacionales de México y reservas equivalentes: Aspectos físicos, sociales, culturales, administrativos, recreativos, biológicos, culturales. Situación actual y propuestas en torno a los parques nacionales de México. Inst. Inv. Eco. México DF: Universidad Nacional Autónoma de México; 1984. p. 237.

11. Secretaria de Medio Ambiente y Recursos Naturales (SEMARNAT). Programa sectorial de medio ambiente y recursos naturales. México DF: SEMARNAT; 2013. p. 41.

12. Bezaury-Creel J, Gutiérrez-Carbonell D. Áreas naturales protegidas y desarrollo social en México. In: Dirzo R, González R, March, IJ, editors. Capital natural de México, Vol. II: Estado de conservación y tendencias de cambio. Comisión Nacional para el Conocimiento y Uso de la Biodiversidad, 2009. p. 385-431.

13. González-Ocampo H, Cortés-Calva A, Íñiguez-Dávalos P, OrtegaRubio A. Las áreas naturales protegidas de México. Investigación y Ciencia. 2014;60:7-15.

14. Cantú C, Wright RG, Scott JM, Strand E. Assessment of current and proposed nature reserves of Mexico based on their capacity to protect geophysical features and biodiversity. Bio Cons. 2004;115: 411-7.

15. Secretaría de Medio Ambiente y Recursos Naturales (SEMARNAT). Unidades de Manejo para el Aprovechamiento Sustentable de la Vida Silvestre. Ciudad de México: Dirección General de Vida Silvestre; 2005. 28 p.

16. Escalante T, Martínez-Meyer E. Ecological niche modeling and wildlife management units (UMAs): an application to deer in Campeche, Mexico. Trop Subtrop Agroecosyst. 2013;16:2.

17. Mandujano S, González-Zamora A. Evaluation of natural conservation areas and wildlife management units to support minimum viable populations of white-tailed deer in Mexico. Trop Cons Sci. 2009;2:237-50.
18. Gallina S, Escobedo-Morales LA. Análisis sobre las Unidades de Manejo (UMAs) de (UMAs) de ciervo rojo (Cervus elaphus Linnaeus, 1758) y wapiti (Cervus canadensis (Erxleben, 1777) en México: problemática para la conservación de los ungulados nativos. Trop Cons Sci. 2009;2:251-65.

19. Marshall E, Newton AC. Non-timber forest products in the community of El Terrero, Sierra de Manantlán Biosphere Reserve, Mexico: Is their use sustainable? Econ Bot. 2003;57:262-78.

20. Marshall E, Schreckenberg K, Newton AC. Commercialization of non-timber forest products; Factors influencing success: Lessons learned from Mexico and Bolivia and policy implications for decision-makers. Cambridge: United Nations Environment Programme/ Earthprint; 2006. 137 p.

21. Zamora MM, Torres-Rojo JM. Estado actual de la información sobre productos forestales no madereros. In: Estado de la información Forestal en México. Santiago de Chile: Departamento de Montes. FAO-Comisión Europea; 2002. p. 179-279.

22. Castillo A, Magaña A, Pujadas A, Martínez L, Godínez C. Understanding the interaction of rural people with ecosystems: a case study in a tropical dry forest of Mexico. Ecosyst. 2005;8: 630-43.

23. Jardel PE. El Manejo Forestal en México: Estado actual y Perspectivas. In: Estado de los bosques de México, Chapela, F, editor. Ciudad de México: Consejo Civil Mexicano para la Silvicultura Sostenible; 2002. p. 69-115.

24. Humboldt A von. Ensayo político sobre el reino de la Nueva España. Mexico D.F. Porrúa, Colecc. "Sepan Cuantos...”, Núm. 39, 5th. Edition, 1991. 698 p.

25. De la Guarida M. Las Leyes de Indias con las posteriores a este código vigentes hoy y un epilogo sobre las reformas legislativas ultramarinas. Sevilla: Digital scan from the Universidad de Sevilla; 1889. 270 p.

26. de Quevedo MA. Explotación y comercio de productos forestales. México Forestal. 1925;3:83-9.

27. Sarré A. Informe sobre la necesaria aplicación de medidas tendientes a corregir las malas prácticas en la explotación de maderas de los bosques de México. México Forestal. 1929;7: 228-34.

28. Mathews AS. Mexican Forest History. J Sust For. 2002;15:17-28.

29. Lartigue F. Indios y bosques: políticas forestales y comunales en la Sierra Tarahumara. Edited by Ediciones de la Casa Chata, Vol. 19. Ciudad de México: Centro de Investigación y Estudios Superiores en Antropologia Social; 1983. 155 p.

30. Hinojosa-Ortiz M. Los bosques de México: relato de un despilfarro y una injusticia. Ciudad de México: Instituto Mexicano de Investigaciones Económicas; 1958. 256 p.

31. Mendoza MR, Rodríguez-Caballero R. Método mexicano de ordenación de montes. Proy. Gral. Ordenación Ftal. UIEF Michoacana de Occidente. Morelia: Unidad Industrial de Explotación Forestal, Michoacana de Occidente; 1959. 82 p.

32. Mendoza-Briseño MA. Perspectivas del manejo forestal en México. Agrociencia. 1983;51:177-87.

33. Hernández-Díaz JC, Corral-Rivas JJ, Quiñones-Chávez A, BaconSobbe JR, Vargas-Larreta B. Evaluación del manejo forestal regular e irregular en bosques de la Sierra Madre Occidental. Madera y Bosques. 2008;14:25-41. 25.

34. Mendoza-Santos JC. Método Mexicano de Ordenación de Montes. Bermejillo: Universidad Autónoma Chapingo-Unidad Regional de Zonas Áridas; 2012. 12 p.

35. Rodríguez-Caballero R. The Mexican method of Forest management. Proc. $5^{\text {th }}$ World For. Congress: Multiple use of forest lands. USA, 1960; pp 486-489.

36. Rodríguez-Caballero R. Discusión de fórmulas para el cálculo de la productividad maderable y exposición del Método Mexicano de Ordenación de Montes de especies coníferas. Monografía 
Forestal. Morelia: Comisión Forestal del Estado de Michoacán; 1958.

37. Mendoza-Briseño MA. Conceptos básicos de manejo forestal. México D.F: Limusa- UTEHA; 1993. p. 161.

38. Dirección General de Aprovechamiento Forestales (DGAF). Normas mínimas de calidad para la formulación de estudios dasonómicos en bosques. Secretaría de Agricultura y Recursos Hidráulicos, 1984; 9 p.

39. Rodríguez-Caballero R. Segundo Estudio Dasonómico del Estado de México. Rancho Guadalupe: Probosque; 1990, 334 p.

40. Secretaria de Agricultura y Recursos Hidráulicos (SARH). Programa Nacional de Desarrollo Forestal por proyectos. México D.F: SARH; 1980. p. 225.

41. Snook L, Negreros P. Effects of Mexico's selective cutting system on pine regeneration and growth in mixed Pine-Oak (PinusQuercus) forest. In: Current topics in forest research: emphasis on contributions by women scientists. Asheville, NC, USA, USDA For Serv Gen Tech Rep, SE-46, 1986, p. 27-31.

42. Torres-Rojo JM. Sostenibilidad del volumen de cosecha calculado con el Método Mexicano de Ordenación de Montes. Madera y Bosque. 2000;6:57-72.

43. Rosales-Salazar P, Olayo-Martínez MA, Morales JA, Álvarez R, Martínez I, Castro S. El Método de Desarrollo Silvícola: una Alternativa en la Producción Forestal y Ordenación de Bosques, Thesis. Chapingo, México: UACH; 1982.

44. Secretaría de Medio Ambiente, Recursos Naturales y Pesca (SEMARNAP). Guía Técnica para la Aplicación del Método de Desarrollo Silvícola. Dirección General Forestal, 1994. 69 p.

45. Corral-Rivas JS, Torres-Rojo JM, Lujan-Soto JE, Nava-Miranda J. Aguirre- Calderón O, Gadow Kv. Density and production in the natural forests of Durango/Mexico. 2016. Forthcoming Allgemeine Forst und Jagdzeitung.

46. Jardel EJ, Maass M, Castillo A, García-Barrios R, Porter L, Sosa J, et al. Manejo de ecosistemas e investigación de largo plazo. Ciencia y Desarrollo. 2008;34:31-7.

47.• Moreno-Sánchez R, Torres-Rojo JM. Decision Support Systems for forest management in Mexico: Their characteristics and context for their creation and evolution. In: Manos B, Paparrizos J, Papathanasiou K, editors. Decision Support Systems in Agriculture, Food and the Environment: Trends, Applications and Advances. Hershey: IGI Global; 2010. pp. 74-100. The paper summarizes the evolution of decision support systems used in Mexico for forest management, highlighting some of their technical characteristics and management principles they are based on.

48. Torres-Rojo JM, Bray DB, Magaña OS. The role of scale in Mexican Community forest management. Working paper 451, Ciudad de México, México, Centro de Investigación y Docencia Económcas; 2008. 26 p.

49. Chapela F. Indigenous community Forest management in the Sierra Juárez, Oaxaca. In: BrayD, Barry D, Merino-Pérez, L. editors. The community forests of Mexico. Austin: University of Texas Press; 2005. p. 91-110.

50. Xi W, Coulson RN, Birt AG, Shang Z, Waldron JD, Lafon CW, et al. Review of forest landscape models: types, methods, development and applications. Acta Ecol Sinica. 2009;29:69-78.

51.• Mendoza-Briseño M, Fajardo JJ, Zepeta J. Landscape based forest management - a real world case study from Mexico. For Ecol Mgmt. 2005;209:19-26. The authors describe an alternative way to manage forest ecosystems in Mexico taking into account risks and uncertainties commonly existent.

52. Cancino J, Gadow Kv. Stem number guide curves for uneven-aged forests development and limitations. In: Gadow Kv, Nagel J, Saborowski J, editors. Continuous cover forestry assessment, analysis, scenarios. Dordrecht: Springer; 2002. p. 163-74.
53. Wehenkel C, Corral-Rivas JJ, Hernández-Díaz JC, Gadow K. Estimating balanced structure areas in multi-species forests on the Sierra Madre Occidental, Mexico. Ann For Sci. 2011;68:385-94.

54. Torres-Rojo JM. Exploring volume growth-density relationship of mixed multiaged stands in northern Mexico. Agrociencia. 2014;48: 447-61.

55. Gómez-Pompa A. On Maya silviculture. Mexican Studies/Estudios Mexicanos. 1987;3:1-16.

56. Toledo V, Ortiz-Espejel MB, Cortés L, Moguel P, Ordoñez MJ. The multiple use of tropical forests by indigenous peoples in Mexico: a case of adaptive management. Cons Ecol. 2003;7(3):9.

57. Gómez-Pompa A, Kaus A. From prehispanic to future conservation alternatives: lessons from Mexico. Proc Natl Acad Sci. 1999;96: 5982-6.

58. Gómez-Pompa A, Flores E, Sosa V. The "pet kot": a man-made tropical forest of the Maya. Interciencia. 1987;12:10-5.

59. Koleff P, Urquiza-Haas T, Contreras B. Prioridades de conservación de los bosques tropicales en México: reflexiones sobre su estado de conservación y manejo. Ecosistemas. 2012;21:6-20.

60. Carneiro RL. Slash and burn cultivation among the Kuikuru and its implications for cultural development in the Amazon Basin. Antropologica Supp. 1961;2:47-67.

61. Harris DR. The ecology of swidden cultivation in the upper Orinoco rain forest, Venezuela. Geog Rev. 1971;61:475-95.

62. Hecht SB. Agroforestry in the Amazon Basin: Practice, theory, and limits of a promising land-use. In: Hecht SB, editor. Amazonia: Agriculture and Land Use Research. Cali, Colombia, Centro Internacional de Agricultura Tropical, 1982. p. 331-371.

63. Maffi L. Biocultural diversity and sustainability. In: Pretty J, Ball A, Benton TJ, Guivant J, Lee D, Orr D, Pfeffer M, Ward H, editors. The Sage handbook of environment and society. London, UK: Sage; 2007. p. 267-77.

64. García-Barrios L, Galván-Miyoshi YM, Valdivieso-Pérez IA, Masera OR, Bocco G, Vandermeer J. Neotropical forest conservation, agricultural intensification, and rural out-migration: the Mexican experience. Bioscience. 2009;59:863-73. The paper summarized the main social, political and economic drivers affecting land use changes in Mexico.

65. Myers N, Tucker R. Deforestation in Central America: Spanish Legacy and American consumers. Environ Rev. 1987;11:55-71.

66. Newton RA. "Good and Kind Benefactors": British Logwood Merchants and Boston's Christ Church. Early American Studies: An Interdisciplinary Journal. 2013;11:15-36.

67. Mell CD.True mahogany. USDA For Serv Bull No. 427, 1917.

68. Galletti HA. Las actividades forestales y su desarrollo histórico. In: Estudio Integral de la frontera México-Belice. Chetumal, México: Centro de Investigaciones de Quintana Roo; 1994. p. 131-98.

69. Flachsenberg H, Galletti HA. El manejo forestal de la selva en Quintana Roo, México. In: Primack RB, Bray DB, Galletti HA, Ponciano I, editors. La Selva Maya: Conservación y Desarrollo. México D.F, Siglo XXI, 1999. p 74-97.

70. Medina B, Cuevas A., Santos M. Unidad Industrial de Explotación Forestal-Maderas Industrializadas de Quintana Roo: Ajuste del proyecto de ordenación. Chetumal, México, Unidad Industrial de Explotación Forestal-Maderas Industrializadas de Quintana Roo, Vol. 3; 1968. 167 p.

71. Rice RE, Gullison RE, Reid JW. Can Sustainable Management Save Tropical Forests?. Sci Am. 1997;276:44-9.

72. Lawrence, A. New approaches to forest survey and inventory in Mexico. London: Overseas Development Institute; 1994. 22 p.

73. Taylor PL, Zabin C. Neoliberal reform and sustainable forest management in Quintana Roo, Mexico: rethinking the institutional framework for the Forestry Pilot Plan. Agric Hum Values. 2000;17:141-56.

74. Apodaca-Martínez M, Millán, Curiel-Alcaraz, Mendoza-Briseño MA, Vargas-Mendoza M, Valdez-Hernández JI, Platas-Rosado 
DE. El Plan Costa como una mejor opción de manejo para especies forestales tropicales de Jalisco. Revista Mexicana de Ciencias Forestales. 2014;5:10-25

75. Peters CM. Economic Botany and management potential of Neotropical seasonally dry forests. In: Dirzo R, Young H, Mooney H, Ceballos G, editors. Seasonally dry tropical forests: ecology and conservations. Washington, DC: Island Press; 2011. p. 239-58.

76. Quesada M, Sanchez-Azofeifa GA, Alvarez-Anorve M, Stoner KE, Avila-Cabadilla L, Calvo-Alvarado J, et al. Succession and management of tropical dry forests in the Americas: review and new perspectives. For Eco Mgmt. 2009;258:1014-24.

77. Peters C. Sustainable Harvest of non-timber plant resources in tropical moist forest: An ecological primer. Washington D.C: World Wildlife Fund, The Nature Conservancy, World Resource Institute; 1994. p. 84.

78. Hernández-Apolinar M, Valverde T, Purata S. Demography of Bursera glabrifolia, a tropical tree used for folk woodcrafting in Southern Mexico: An evaluation of its management plan. For Eco Mgmt. 2006;223:139-51.

79. Brosi B, Peters C, Ambrosio M, Purata S, Aguirre H. Plan de Manejo Forestal de Copalillo. Bienes Comunales de San Juan Bautista, Jayacatlán, Oaxaca, México, 2000. 349 p.

$80 . \bullet$ Antinori C, Bray DB. Community forest enterprises as entrepreneurial firms: economic and institutional perspectives from Mexico. World Dev. 2005;33:1529-43. The authors showed the main differences between community forestry and private forestry in Mexico.

81. Torres-Rojo JM, Magaña-Torres OS. Management of Mexican community forests with timber production objectives. Allgemeine Forst und Jagdzeitung. 2006;177:63-71.

82. Torres-Rojo JM, Amador-Callejas J. Características de los núcleos agrarios forestales en México. In: Torres-Rojo JM, editor. El desarrollo forestal comunitario: La política pública. México DF: Centro de Investigación y Docencia Económicas-Coyuntura y Ensayo; 2015. p. 15-38.

83. Fuentes-López ME, Salazar JAG, Sánchez FJZ, Matus-Gardea JA. Políticas que afectan la competitividad de la producción de madera aserrada en México. Madera y Bosques. 2008;14:29-39.

84. Chapela, G. Conservar ganando. Competitividad de las empresas sociales forestales. In: Chapela, F, editor. Estado de los bosques de
México. Ciudad de México: Consejo Civil Mexicano para la Silvicultura Sostenible; 2002. p. 168-97.

85. Robles-Berlanga HM. Ejidos y comunidades en México: Problemas y perspectivas. In: Reyes J, D'Acosta A, editors. Memorias del Taller "Propiedad Social y Servicios Ambientales", Ciudad de México: Consejo Civil Mexicano para la Silvicultura Sostenible-Comisión Nacional Forestal; 2012.

86. Mathews AS. Instituting nature: authority, expertise, and power in Mexican forests. Cambridge: MIT Press; 2011. p. 303.

87. Barajas G. Las políticas de administración de la pobreza en México: Ayer y hoy. Foro internacional. 2002;42:63-98.

88. Negrete-Fernández G, Aguilar-Urista E. Territorios rurales, política de planeación y ordenamiento ecológico local-comunitario en México. In: Anta-Fonseca S, Arreola-Muñoz A, González-Ortiz M, Acosta-González J, editors. Ordenamiento territorial comunitario: Un debate de la sociedad civil hacia la construcción de las políticas pública. Ciudad de México: Instituto Nacional de Ecología, Instituto para el Desarrollo Sustentable, Grupo de Innovación Ambiental, Grupo de Estudios Ambientales; 2006. p. $19-40$.

89.• Messier C, Puettmann KJ, Coates KD. Managing forests as complex adaptive systems: building resilience to the challenge of global change. New York: Routledge; 2013. p. 353. This book shows the need manage forests as complex systems and highlights deficiencies of assumptions made by traditional forest management practices.

90. Becker P. Sustainability science: managing risk and resilience for sustainable development. The Netherlands: Elsevier; 2014. p. 295.

91. Silva F, Pérez-Verdín G, Wehenkel C. Patterns of tree species diversity in relation to climatic factors on the Sierra Madre Occidental, Mexico. PLoS One. 2014;9(8):e105034.

92. Lujan-Soto JE, Corral-Rivas JJ, Aguirre-Calderón OA, Gadow K. Grouping forest tree species on the Sierra Madre Occidental, Mexico. Allgemeine Forst und Jagdzeitung. 2015;186:63-71.

93.•• Tewari VP, Sukumar R, Kumar R, Gadow K. Forest observational studies in India - past developments and future prospects. For Ecol Mgmt. 2013;316:32-46. The authors outlined the importance of observational studies to guide alternative ways of forest management in complex environments. 